\title{
FEMORAL ARTERY TRANSECTION DUE TO BULL GORE INJURY: CASE REPORT
}

\author{
Rajashekar S. B1, P. Ravikumar Reddy², Somashekhar Samagandi ${ }^{3}$
}

\section{HOW TO CITE THIS ARTICLE:}

Rajashekar S. B, P. Ravikumar Reddy, Somashekhar Samagandi. "Femoral Artery Transection due to Bull Gore Injury: Case Report". Journal of Evolution of Medical and Dental Sciences 2015; Vol. 4, Issue 16, February 23; Page: 2826-2829, DOI:10.14260/jemds/2015/405

\begin{abstract}
Bull is a regular domestic animal in India and injuries due to the bull gore are common involving various parts of the body like abdomen, chest, perineum leading to various types of tissue destruction which may cause fatal outcomes and high risk of infection. But bull gore injury occurring over medial side of thigh is rare which is causing femoral artery transaction. Here we report a case of bull gore injury to right thigh leading to femoral artery injury leading to ischaemia of the limb, successfully saved the limb by using reversed saphenous vein interposition graft.
\end{abstract}

KEYWORDS: Bull gore, femoral artery, saphenous vein.

INTRODUCTION: The incidence of vascular injury following bull horn goring is nearly $7 \%$ and considered to be more severe and possibility of serious complications like limb loss or even death ${ }^{1}$. Most common part to be injured is the lower extremity. Timely intervention will save life and also limb $^{1}$. But bull gore injury occurring over medial side of thigh is rare which is causing femoral artery transaction. Here we present a 35 year old male who got injured due to bull horn goring to his right thigh leading to ischaemia of right lower limb due to femoral artery injury, successfully saved the limb by using reversed saphenous vein interposition graft.

CASE REPORT:A 35 year old male patient came to casuality with complaint of bull horn goring to right thigh. On examination patient is conscious having anxious look in his face. Pulse rate 120 per minute. Blood pressure 70 systolic. Severe pallor present. Primary survey showed injury to right thigh with active bleed. Distal pulse was absent and limb was getting cold. No other injuries noted. Pressure applied to the bleeding site and resuscitation started immediately with crystalloids, colloids and blood. To stabilize blood pressure. Bed side Doppler showed distal absent blood flow. Patient transferred to major operation theatre for emergency exploration.

On exploration femoral artery found to be transected in the lower third of the thigh with ragged walls of about $5 \mathrm{~cm}$ proximal to transection with active bleed from anterior aspect of the proximal ragged part. Proximal and distal ends are clamped with bull dog clamps. Proximal and distal ends are flushed with heparin solution and blood flow noted in both segments. The ragged part of the proximal segment is trimmed to obtain fresh edges after clearing the surrounding adventitious tissue.

A sufficient length of saphenous vein is harvested from left lower limb after clamping the tributaries using mini liga clips. The direction of the vein is reversed and end to end anastomosis is done between the proximal and distal ends using proline 7-0 suture. Vein graft length was about 20 $\mathrm{cm}$. Anastomosis was done by interrupted sutures. And clamps removed to see pulsations transmitted through vein and limb pulsations begin to be felt with limb saturation being $98 \%$. Limb also achieved body temperature. Sartorious muscle is used to cover the vein graft and faciotomy done 


\section{CASE REPORT}

to the right leg by medial and lateral incisions. Thigh wound covered by sartorious is left to heal by granulation for skin grafting.

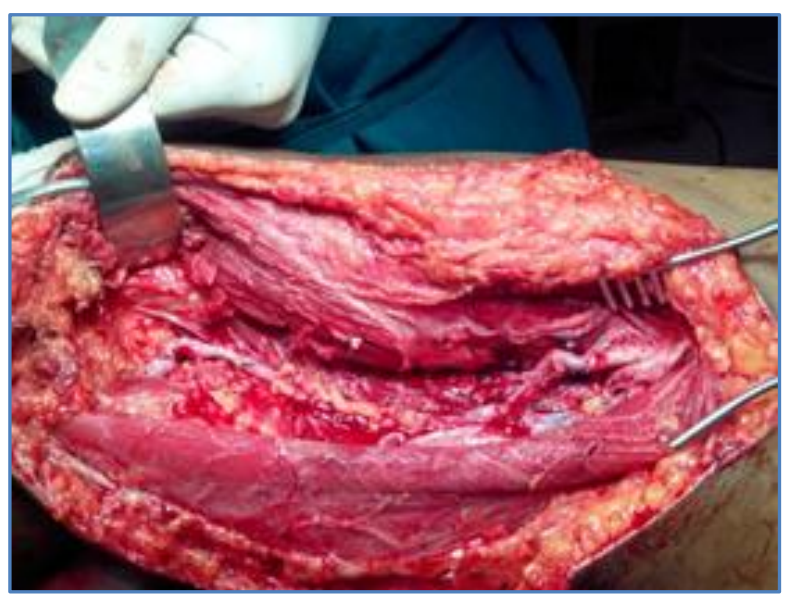

Fig. 1: Saphenous vein reversed interposition graft after anastomosis

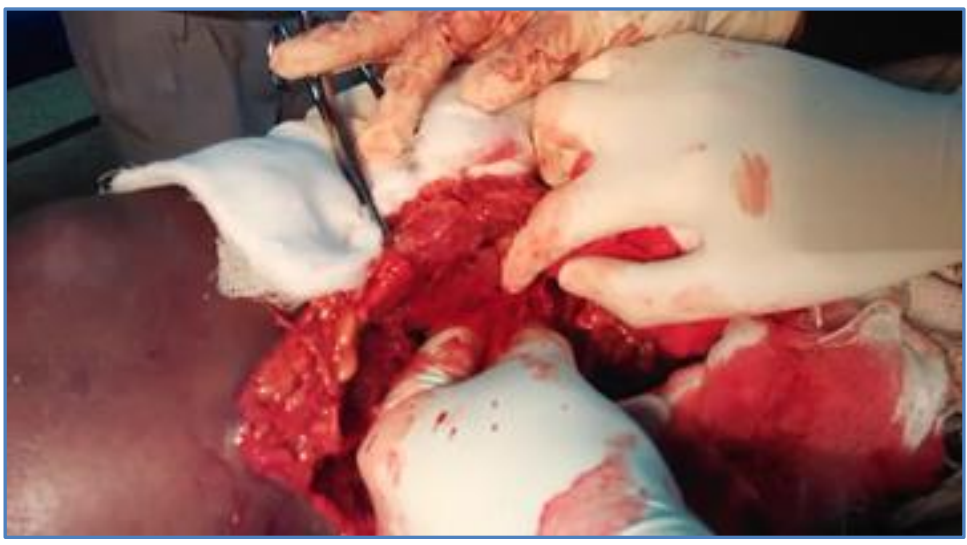

\section{Fig. 2: Femoral artery injury with active bleed}

Total 6 pints of blood transfused throughout the process. Dressing opened on day 2 and blood ooze noted from the raw surfaces indicating adequate perfusion. Patient was encouraged to take adequate oral liquids and maintenance intravenous fluids of 5 pints given daily and observed for ischaemic reperfusion injury. Patient recovered fully without any limb loss and the raw surfaces are covered by split skin grafting and fasciotomy is closed by secondary suturing and patient started on physiotherapy.

DISCUSSION: Patients with bull horn injuries should be classified as major trauma patients and should be treated at the bull-ring or transferred to hospitals depending on the severity of their injuries. Vascular lesions are immediate threat to the life of the patient and indicating that the patient should be stabilized at the site, controlling the haemorrhage, and transfer to a hospital for definitive treatment should not be delayed ${ }^{2}$. Vascular lesions can be treated using different techniques and 


\section{CASE REPORT}

depending on the type of injury by-pass, usually with the internal saphenous vein ${ }^{3}$. Here in this case we used reversed saphenous vein interposition graft.

Patients tend to do well in the days to weeks after vascular trauma, so the attention turns to performing a durable vascular repair and maximizing functional outcome. Amputations are typically only needed for patients with mangled extremities (eg, lawn mower injury) and/or delayed presentation. ${ }^{4}$ Dalsing et al reported on late follow-up of three patients with reversed saphenous vein grafts (21-49 months), none of whom experienced graft stenosis or dilatation on duplex ultrasound scan. Dorweiler et al reported excellent patency among adults receiving vein interposition grafts after arterial trauma; on follow-up of 23 to 139 months, there were no late thrombosis. ${ }^{5}$

Ischaemic reperfusion injury is one of the important concern following the arterial repair of the limb. ${ }^{6}$ Larcan et al (1973) reported that for the development of revascularization syndrome the following conditions should be there. ${ }^{6}$

a. Ischaemia has to be on the bulkier muscle groups,

b. Ischaemia has to be complete. ${ }^{6}$

In our case eventhough major blood vessel supplying the bulky muscles is injured, because of good collaterals before repair may have avoided this devastating reperfusion injury.

CONCLUSION:The possibility of the vascular injury following bull gore injury to the extremities should be kept in mind and to be managed with timely intervention as soon as possible. Bull gore injuries can be severe especially to limbs causing vascular injury and we recommend on site bleeding control and timely intervention to repair the injury to avoid limb loss.

\section{REFERENCES:}

1. Bull Horn Injuries: Endovascular Repair of an External Iliac Artery Thrombosis; ciresp. 2013; $x$ $\mathrm{x}(\mathrm{x} \mathrm{x}): \mathrm{x} \mathrm{xx}-\mathrm{x} \mathrm{xx}$.

2. Miñ ano A, Jime'nez R, Reyes JM, Bastwich B, Lo'pez-Collado M. Distribucio'n de lesionestrauma'ticas en los festejostaurinos: haciaunaracionalizacio'n de la asistencia. Revista Espan ola de Investigaciones Quiru' rgicas. 2007;10:199-203.

3. Vaquero C, Arce N, Gonza'lez-Fajardo J, Beltra'n de Heredia J, Carrera S. A nossa experiencian ostraumatismos vascular escaus adosporcornos de touros. Revista Portuguesa de Cirurgia Cardio-Tora'cica e Vascular. 2008;15:217-20.

4. Dalsing, M.C., Cikrit, D.F., and Sawchuk, A.P. Open surgical repair of children less than 13 years old with lower extremity vascular injury. J Vasc Surg. 2005; 41: 983-987.

5. Sarah P. Pradka, MD, Cameron M. Akbari, MD John J. Ricotta, MD John M. Keshishian, MD; Durability of saphenous vein grafts: 44-year follow-up of a saphenous vein interposition graft in a pediatric patient; Journal of Vascular Surgery, July 2012Volume 56, Issue 1, Pages 216-218.

6. Volanska M, Zavacky P, Bober J; Ischaemic reperfusion damage of tissue and critical limb ischaemia; Bratis L Lek Listy 2006; 107(6-7): 264-268. 


\section{CASE REPORT}

\section{AUTHORS:}

1. Rajashekar S. B.

2. P. Ravikumar Reddy

3. Somashekhar Samagandi

\section{PARTICULARS OF CONTRIBUTORS:}

1. Assistant Professor, Department of Surgery, VIMS, Bellary.

2. Assistant Professor, Department of Surgery, VIMS, Bellary.

3. Associate Professor, Department of Plastic Surgery, VIMS, Bellary.

\section{FINANCIAL OR OTHER}

COMPETING INTERESTS: None

\section{NAME ADDRESS EMAIL ID OF THE} CORRESPONDING AUTHOR:

Dr. P. Ravikumar Reddy, Department of Surgery,

VIMS, Bellary.

E-mail: drravireddy@gmail.com

Date of Submission: 18/02/2015.

Date of Peer Review: 19/02/2015.

Date of Acceptance: 20/02/2015.

Date of Publishing: 23/02/2015. 